\title{
Exploration and practice of graduation project of local characteristic cultural elements in clothing and costume design
}

\author{
Liu Yongru \\ Nanchang Institute of Science \& Technology, Nanchang 330108, China
}

\begin{abstract}
Key words: local characteristics; clothing design; graduation design; Tang tomb murals; cultural elements

Abstract: Without rich culture, it could not create deep and full of tension in the clothing design, clothing design in the training of personnel. In addition to a solid foundation, bold design concept and innovation ability, it also should be oriented to the local economy and culture, make the design of the clothing has more broad art space. The theme of clothing and local cultural characteristics of the graduation design reflects the design culture and connotation based on the develop ideas of the students, which is mainly to Tang tomb murals as an example, to explore a new method of clothing design. In the graduation design of professional clothing, the local cultural and artistic use of murals in the clothing design, you can use the local cultural and artistic style of bold innovation design of modern clothing, which provides a new idea for modern fashion design.
\end{abstract}

\section{Introduction}

China has a long history and fashion culture is colorful, from ancient to modern times, which have the honor of our kingdom of dress, rich historical culture provides a source of inspiration for fashion design masters, is also the basis for the innovation and development of Chinese costume design, as a professional fashion design graduates need the effective inheritance and application. In twenty-first Century China traditional clothing how to innovation, follow the fashion of the world has become a new kind of values, but not discard our own traditional culture, which requires that the inheritance of local culture, and the traditional design method innovation, the integration of local culture and modern fashion design elements into a new fashion for the clothing design, make the local clothing innovation in the design and the use of inheritance.

\section{The local characteristics of cultural elements into the dress graduation project}

Integrating the local characteristic culture into the graduation design of dress can reflect the details of the traditional culture, and also make the design of clothing fashionable and charming. There are many traditional local culture, has great significance for the clothing design drawing, cross stitch and paper cutting, can use these innovative fashion design of local characteristics and folk art tradition, these cultural characteristics and integration, graduation design can be in field trips, longer cycle, can achieve very good fusion.

Hand drawing.Hand is China's traditional culture and art, has obvious local characteristics, such as local painting, murals and so on, but in the clothing design, can be drawn on the fabric in hand painting, reflect the local characteristics of various artistic style. The use of hand painting can highlight personality, make clothing design more innovative features, to achieve the purpose of innovative traditional fashion design. So in the graduation design of professional clothing, students can go to the field investigation, combined with the local characteristics of the hand-painted art, this is mainly with murals as the main cultural and artistic characteristics, explore the feasibility of its use in clothing in graduation design. 
Cross stitch.Cross stitch is an ancient culture and art, the earliest in Europe has been born, in the cross stitch embroidery can be a variety of lines embroidered in the cross lattice, through a grid of embroidery, to get different features of the design. Cross stitch has different cultural features in different places, and the visual impact of cross stitch embroidery on clothes can obviously improve the clothes, clothing in graduate design professional, students can find unique around the cross stitch, cross stitch embroidery in their graduation design work clothes in the complete works of clothing, at the same time, also can show the local cultural characteristics.

The art of paper cutting. The paper-cut art also has the obvious local culture artistic characteristic, but applies in the clothing design to display in the hollow design. The use of paper cutting art in clothing design has many advantages, do not let its hollow patterns can be designed exquisite and clever, it will be embedded in the clothing, when not needed, you can pick it off at any time. The combination of local culture paper-cut, in addition to clothing has a beautiful appearance, can also be a cultural and artistic charm into the fashion clothing, so as to improve the artistic charm, elegance for the graduation design.

\section{The feasibility of the application of a local mural in the clothing graduation design}

The Tang Dynasty tomb murals of Tang Dynasty is reflected image, has obvious characteristics of local culture, and with the customs of the tomb murals was popular, the scale and level of the tomb murals enlarging, the murals represent the cultural characteristics of the times. With the advancement of archaeological excavation of the tombs, found a large number of murals, its artistic value is extremely high, only in the Xi'an Museum, is a collection of 14 Tang Dynasty tomb murals of more than 500, close to 300 paintings for the repair, restoration of the mural has good high artistic level. The clothes on these murals have obvious national characteristics and characteristics at that time, as shown in Figure 1.

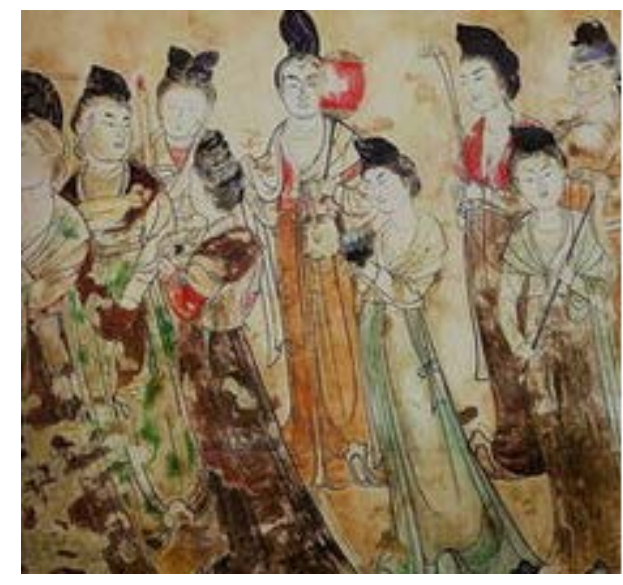

Fig.1 The features of murals in costumes

As shown in Figure 1, in the Tang Dynasty tomb murals show was a variety of women's clothing, so in the process of graduation design students in the fieldwork, the artistic features of murals, arouse the desire to create fashion design, will feel the situation into its fashion design, combined with the local folk customs and the local culture, modern clothing design innovative. This kind of fashion design experience can be applied not only in the graduate design, but also in the classroom teaching. 


\section{The usage exploration for graduation project of Tang custom in the local mural painting in tomb chamber}

In the graduation design of professional clothing, the local cultural and artistic use of murals in the clothing design, in addition to clothing with the classic clothing image, it can be combined with the local culture of Tang Dynasty and the artistic style of the creative design bold to modern fashion, with fashion design to provide ideas for the times.

The murals and costumes style. Costumes is a new style of costume design in recent years popular, modern designers have given a lot of new era elements. In costumes clothing graduation design, can be combined with the tomb mural art, traditional costumes and the structure styles retained, focus on highlighting the cultural characteristics, will not meet the constantly refined aesthetic details of the times, the traditional costumes that highlight the cultural characteristics, and to show the spirit of the times. For example, in the design, can use the flowers, birds, fish, insects, grass and other popular costumes in the painting pattern, and then together with the modern drawings, cross stitch and paper-cut art, design distinctive dress costumes.

The costumes design concept and modern fashion design.The murals in the tomb reflect the cultural spirit of the Tang Dynasty, and it contains rich dress culture and social life at that time. In the Tang Dynasty, the female figure is plump for the United States, which makes the clothes on the beam is relatively thin gauze bra, coat, wearing a skirt, which reflects the openness of social thoughts at that time, it was the fashion design style is bold pursuit of freedom and full artistic effect. The students in the graduation design, can be combined with the characteristics of murals, bold exploration of modern design ideas, transparent, low cut high waist with the exposure of course design concept not only the performance of the body, but is full of female development and relatively independent from the era of aesthetic embodied by the explore for the clothing design material of graduation design, so as to improve the ability and effect of graduation design.

\section{Conclusion}

To explore and research the design graduation fashion professional geographical and cultural characteristics based on graduation design can make students more objective and initiative, enhances the design details of the students, contribute to the development of design ideas, the formation of personality design. The local characteristics and cultural elements into the fashion design process, on the one hand, can make full use of existing resources, develop the regional advantages, on the other hand, can make local schools to strengthen the artistic work, contribute to the protection, inheritance and development of local history and culture, the local cultural characteristics into the graduation design of clothing specialty the process is feasible, and is of great significance.

\section{Reference}

[1] Li Yanyan. Study on the fashion of Chinese characteristic clothing after the founding of the people's Republic [J].. Mass literature and art,2011 (18).

[2] YuanXi. Research and application in modern fashion design [J]. Modern Decorative Theory,2014 (10).

[3] Li Feng, Jiang Lulu. Application of design in modern product[J]. Design, 2014 (02). 
[4] Lu Jie. Functional interpretation of silk fabric in the design of haute couture[J]. Decoration,2013 (07).

[5] Zeng Hong. Embroidery technique in the design of modern cheongsam dress[J]. Silk,2013 (04).

[6] Dai Lu. Analytical Chinese traditional, art [J].Writer,2012 (06).

[7] Ma Junshu, Zhou Rui. The application of sculptural art in dress design [J]. Shandong Textile Economy,2010 (06).

[8] Meng Xunmin. Visual aesthetics interpretation of modern clothing art [J]. Journal of Wenzhou Vocational and Technical College,2008 (02).

[9] Chen Xiaoling. Decorative techniques for dresses[J]. Sichuan silk,2008 (02).

[10] Yuan Jianxia. Analysis of the application of Clay Dog elements in modern design in Henan, Huaiyang[J]. Decoration,2013 (06).

[11] $\mathrm{Wu}$ Fei. The creative transformation of folk art in tourist souvenirs taking clay dogs in Huaiyang, for example[J]. Decoration,2013 (05).

[12] Ding Junhua. Men's shirts, wearing and matching rules[J]. Chinese and foreign entrepreneurs,2013 (02).

[13] Sun Rui. The art form of clay dog[J]. Art Education,2007 (10).

[14] Yu Wenyu, Zhou Wuzhong. Five color view and Chinese traditional color phenomenon[J]. Art Hundred. 2007 (05).

[15] Li Weiqi. Design and research of visual recognition system for clothing brand[J]. Beauty and age (I) ,2012 (10).

[16] Huang Yaqin, Xiang Zhen. Analysis of the style and cultural connotation of batik in Guizhou[J]. Textile Herald,2014 (06). 